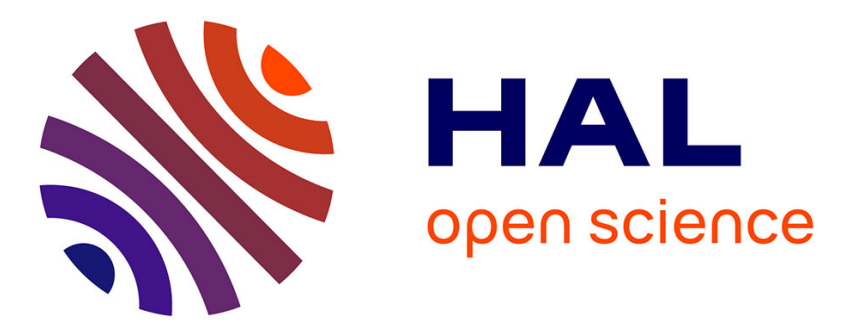

\title{
Anode aging in polymer electrolyte membrane fuel Cells I: Anode monitoring by ElectroChemical impedance spectroscopy
}

Salah Touhami, Laetitia Dubau, Julia Mainka, Jérôme Dillet, Marian

Chatenet, Olivier Lottin

\section{To cite this version:}

Salah Touhami, Laetitia Dubau, Julia Mainka, Jérôme Dillet, Marian Chatenet, et al.. Anode aging in polymer electrolyte membrane fuel Cells I: Anode monitoring by ElectroChemical impedance spectroscopy. Journal of Power Sources, 2021, 481, pp.228908. 10.1016/j.jpowsour.2020.228908 . hal-02937513

\section{HAL Id: hal-02937513 https://hal.science/hal-02937513}

Submitted on 6 Jan 2022

HAL is a multi-disciplinary open access archive for the deposit and dissemination of scientific research documents, whether they are published or not. The documents may come from teaching and research institutions in France or abroad, or from public or private research centers.
L'archive ouverte pluridisciplinaire HAL, est destinée au dépôt et à la diffusion de documents scientifiques de niveau recherche, publiés ou non, émanant des établissements d'enseignement et de recherche français ou étrangers, des laboratoires publics ou privés. 


\title{
Anode Aging in Polymer Electrolyte Membrane Fuel Cells I: Anode Monitoring by ElectroChemical Impedance Spectroscopy
}

\author{
Salah Touhami ${ }^{1}$, Laetitia Dubau ${ }^{2}$, Julia Mainka ${ }^{1}$, Jérôme Dillet ${ }^{1}$, Marian Chatenet $^{2}$, Olivier Lottin ${ }^{1}$ \\ ${ }^{1}$ LEMTA, CNRS, Université de Lorraine, Nancy, France \\ ${ }^{2}$ Univ. Grenoble Alpes, Univ. Savoie Mont Blanc, CNRS, Grenoble INP (institute of engineering, Univ. \\ Grenoble Alpes), LEPMI, 38000 Grenoble, France
}

\begin{abstract}
Degradation of polymer electrolyte membrane fuel cells (PEMFC) is investigated through an accelerated stress test (AST) consisting of load-induced humidity cycling combined with open circuit voltage. This combined stressor-AST was designed to mimic real operating conditions. Commercially available membrane-electrode assemblies with an initial voltage of about $0.7 \mathrm{~V}$ at $0.5 \mathrm{~A} . \mathrm{cm}^{-2}$ showed a performance drop of about $900 \mu \mathrm{V} \cdot \mathrm{h}^{-1}$. Their operation was followed by monitoring various parameters such as polarization plots, electrode electrochemical surface area, hydrogen permeation and electrochemical impedance spectra. The results demonstrate that, although initially, the anode may be ignored to model the impedance data, this is no longer possible during the AST. Experimental data show that, beyond classical cathode and membrane degradations, the cell undergoes pronounced anode degradations, that significantly affect the cell performances. Local potential measurements excluded the anode degradation to be linked to electrode potential cycling, the latter remaining always between 0 and $0.2 \mathrm{~V}$ vs reference hydrogen electrode. Classical mechanisms of $\mathrm{Pt} / \mathrm{C}$ degradation may thus not be at stake here, but rather mechanical destabilization of the anode microstructure under wet-dry cycling. The temperature elevation at high current density, known to entail local membrane dehydration may be an aggravating factor.
\end{abstract}

\section{Introduction}

Durability and cost remain the two main barriers to the large-scale deployment of Polymer Electrolyte Membrane Fuel Cells (PEMFC). Although significant progress has been made, they still not meet -for instance- the targets set by the US Department of Energy (DOE) for the automotive and stationary applications [1]. The necessity to keep costs as well as performances at reasonable levels led the PEMFC community to widely (if not only) use carbon-supported platinum (Pt) for electrodes and thin PFSA membranes as electrolyte. Neither of these are really durable materials in PEMFC operation but, currently, they remain without any convincing alternatives. Besides, the materials composing the Membrane-Electrode Assemblies (MEA) display significantly different failure modes, which narrows the range of appropriate operating conditions in which the whole cell can operate rather durably. In addition, the degradation of one component can also impact one of the others (in other words, it can "contaminate" the others). To analyze, better understand, and eventually limit degradation mechanisms of PEMFC materials and cells without having to operate the whole system for several thousands of hours, the scientific community has developed a variety of accelerated stress test (AST) procedures targeting single components or materials, as well as whole cells and stacks [2]. The most common AST protocols include:

- Open Circuit Voltage (OCV) to chemically attack the PFSA membrane, with -possiblyrelative humidity $(\mathrm{RH})$ cycling to induce additional mechanical stresses [3].

- Potentiostatic hold under nitrogen to investigate carbon corrosion.

- Potential cycling to analyze catalyst (Pt) sintering and dissolution [2, 4-5].

Other more complex ASTs can also be carried out at the cell or stack levels to investigate degradation mechanisms linked with common -but delicate- operating conditions, such as steady-state (constant current or voltage) or potential/load cycling [4, 6], start-up/shut-down cycles [2, 7], hydrogen starvation with a dead-ended anode [8,9], temperature cycling, and even freeze/thaw protocols [10, 11].

In all of these cases, AST are designed to accelerate the rate of degradation of the fuel cell and thus save time and resources compared to real conditions. However, in light of the current development of more durable materials, there is an increasing need for more severe protocols targeting separately or simultaneously the different components of the fuel cell, to allow a good understanding of the 
degradation mechanisms and possibly of the interaction between them: in this work we used a protocol based on RH and load cycling that can, at least in some cases, impact the anode, cathode and membrane simultaneously.

The results of the AST are then interpreted in terms of performance decay, electrochemical surface area (ECSA) losses or, when more in-depth studies can be performed, material degradations [12, 13]. However, evaluating PEMFC materials degradations requires either to fully stop the Fuel Cell (FC) to remove the components that will be analyzed, or to wait till the End-of-Life (EoL) of the system. As a matter of fact, monitoring in detail the state of health of a FC in operation (non-destructive and without altering the cell functioning) is not a simple task. Although operando protocols can be implemented, they require either a temporary shut-down (i.e. to measure the catalysts' ECSA or hydrogen permeation through the membrane) or to operate the FC in well-controlled conditions to perform Electrochemical Impedance Spectroscopy (EIS) [4, 8-9].

Although widely used to study the operation of PEMFC, EIS remains a complex tool: experimental data are somewhat delicate to interpret because the wide range of physical phenomena occurring in the MEA and the flow field plates are both individually not straightforward and interdependent. Therefore, impedance models are often based on oversimplified equations or conversely, include too many correlated parameters. A typical example of the complexity of the phenomena governing fuel cell electrical behavior are the oscillations of oxygen concentration resulting from the measuring signal, that propagate along the gas channels and makes more difficult the interpretation of the low frequency loop [14-15]. In addition, most of the impedance models assume Fickian oxygen diffusion, although, at least in fuel cells fed with air, Stefan-Maxwell equations should be used as in most stationary models [16-17]. In this regard, oxygen diffusion and thus the low frequency impedance are strongly dependent on the overall convective flux and as a result, on water management [18]. However, due to the (relatively) long characteristic times of oxygen transport in the channels or through the porous layer, these limitations do not apply to the high frequency region of the impedance spectra. As such, the high frequency impedance of a PEMFC remains mostly governed by the cathode reaction kinetics [19], but at least in some cases, considering the anode in the Electrical Equivalent Circuit (EEC) is necessary to improve the quality of the fit of the model to the experimental data. Since the anode has - in regular operating conditions - a slight but measurable impact on fuel cell impedance, this means that it becomes possible to monitor its ageing while performing AST. It is usually agreed by the research community that most of FC lifetime issues presumably originate from the cathode [20,21], hence anode degradation has been rarely studied in the literature. This common belief may however not apply to all systems and operating conditions: for example, Schwämmlein et al. recently showed that anode ageing may be significant in the case of repeated start-up and shut-down - because of potential cycling - and have a measurable impact on the FC performance [22].

In this work, PEMFC ageing is characterized during an AST consisting in load-induced humidity cycling combined with OCV by monitoring various parameters such as FC performance, electrode ECSA, hydrogen permeation and impedance spectra; beyond classical survey of the cathode and membrane alterations, an emphasis on possible anode degradation is also made.

\section{Experimental setup}

This work was carried out using a $30 \mathrm{~cm}^{2}$ segmented cell with 5 straight parallel gas channels $(30 \times 1$ $\mathrm{cm}^{2}$ active area) made of 316L stainless steel with a thin coating of gold to lower the electric contact resistance with the gas diffusion layer. The land and channel widths are $1 \mathrm{~mm}$ each on the anode and cathode sides and their depth is $0.7 \mathrm{~mm}$. Current collection on the cathode side is done independently on 20 electrically isolated segments along the channel length. The anode side is not segmented. The cell is also equipped with an auxiliary channel on the cathode side. This channel is parallel to the air channels and feeds local Reference Hydrogen Electrodes (RHE), allowing the measurement of local anode and cathode potentials. For this reason, we used tailored MEA, with a membrane much broader than the anode and cathode active surfaces and without backing layers, so that the 20 Gas Diffusion Electrodes (GDE) can be placed next to the Gas Diffusion Layers (GDL), on the cathode side (Figure 1). The hydrogen auxiliary channel is divided into 20 segments electrically isolated from each other as well as from the cathode flow field, so that the potential of the $20 \mathrm{GDE}$ can be measured independently. For this work, the reference electrodes were SGL 29BC GDE with a Pt loading of $0.3 \mathrm{mg}_{\mathrm{Pt}} / \mathrm{cm}^{2}$ cut into circles of $5 \mathrm{~mm}$ in diameter. More details regarding the measurement of the anode and cathode local potentials as well as the overall architecture of the cell are available in references [8,9] and [23, 24]. This generation of cell was only improved regarding gas-tightness, to allow operation up to 1.5 bar (absolute 
pressure) and in terms of machining and dimension accuracy: the segments are now held together thanks to a layer of Epoxy resin and then fixed to a support plate.

The MEA were fabricated according to our specifications by an external supplier and are based on Nafion ${ }^{\circledR}$ XL100 membranes. The gas diffusion layers were $235 \mu \mathrm{m}$ thick Sigracet 28 BC. The GDL were compressed to $175 \mu \mathrm{m}$ using PTFE gaskets to control their thickness. Pt loadings were 0.1 $\mathrm{mg}_{\mathrm{Pt}} \cdot \mathrm{cm}^{-2}$ for the anode catalyst layer and $0.3 \mathrm{mg}_{\mathrm{Pt}} \cdot \mathrm{cm}^{-2}$ for the cathode; in all cases, high surface area carbon (HSAC, $800 \mathrm{~m}^{2 \cdot \mathrm{g}^{-1}}$ ) was used as the support of the Pt nanoparticles. This choice optimizes the cell performances compared to a more graphitized carbon support, but at the expense of durability. Each new MEA was subjected to a 2-hour conditioning stage consisting of the repetition of potentiostatic current steps with voltages set to OCV (30 s), $0.6 \mathrm{~V}(45 \mathrm{~s})$ and $0.3 \mathrm{~V}(60 \mathrm{~s})$.

The cell was fed in counter-flow configuration, so that segment \#1 corresponds to the air inlet at the cathode and $\mathrm{H}_{2}$ outlet at the anode. Similarly, segment \#20 corresponds to the air outlet at the cathode and $\mathrm{H}_{2}$ inlet at the anode. Unless otherwise stated, the temperature of the $\mathrm{FC}$ was maintained at $80^{\circ} \mathrm{C}$, the hydrogen and air stoichiometries were set to 1.5 and 2, respectively. The outlet (absolute) pressure being set to 1.5 bar on both sides and the relative humidity of gases (air, hydrogen and nitrogen) at the FC inlet being $50 \%$.

The authors would like to stress that, due to its particular geometry -i.e. parallel straight channels-, the overall performances of this cell may be lower than with a more regular configuration -i.e. with serpentine channels, for instance.

Nitrogen can be introduced at the anode and cathode to monitor the electrode ECSA (by cycling the cell voltage between 0.1 and $0.8 \mathrm{~V}$ at a sweep rate of $50 \mathrm{mV} . \mathrm{s}^{-1}$ ) and to assess hydrogen crossover through the measurement of the permeation current (at $0.6 \mathrm{~V}$ ). The opposite electrode is thus fed with hydrogen to play the role of a counter and reference electrode. The cell pressure was controlled at the exit of the electrode compartments thanks to pressure regulators installed downstream of water condensers and membrane dryers used to remove water from the exhaust gases. In normal operation, the overall current produced by the FC is given by the electronic load (Armel 0-100A/0-10V). When voltammograms and hydrogen permeation were recorded, the current was measured using a $5 \mathrm{~m} \Omega$ shunt resistance for a better accuracy. In all cases, the local currents (i.e. currents flowing through each segment of the FC) were measured using Sensitec CMS3000 MagnetoResistive sensors due to their high accuracy, versatility, and dynamics.

Impedance data were measured in galvanostatic mode in $\mathrm{H}_{2}$ /air configuration at 0.5 A.cm ${ }^{-2}$ with a perturbation amplitude limited to $50 \mathrm{~mA}$ (peak to peak), with frequencies ranging from $20 \mathrm{mHz}$ to $10 \mathrm{kHz}$. We paid attention to the impact of the inductance of connecting wires on the system impedance and tried to reduce it as much as possible.

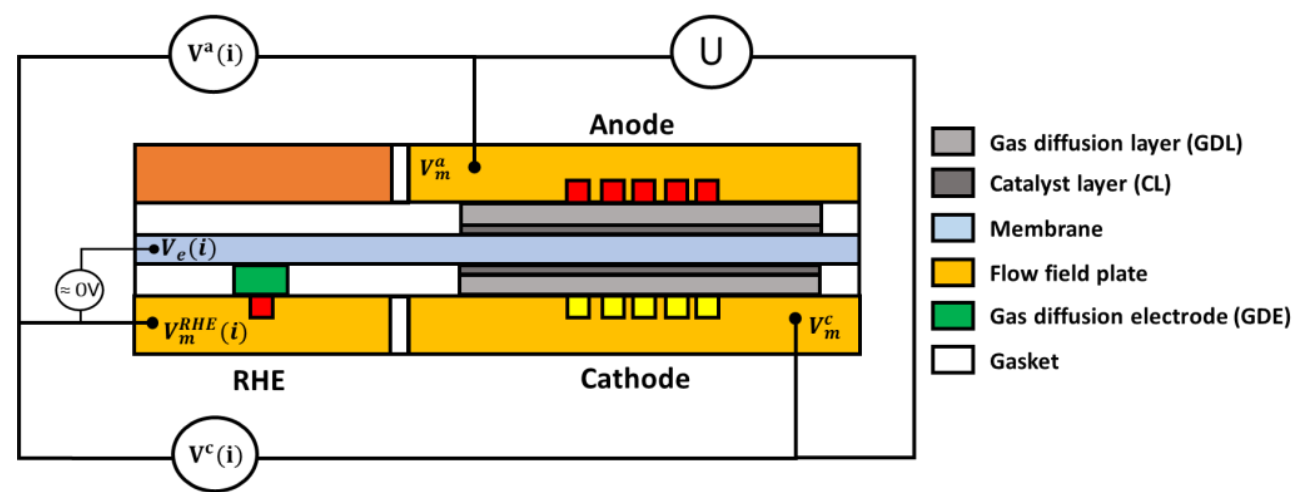

Figure 1. Cross-sectional view of the segmented cell with references electrodes. For each segment, the reference electrodes give access to the local electrolyte-average-potential and thus to the anode and cathode potentials of each segment (adapted from [8]).

\section{AST protocols}

The most severe accelerated aging protocol that was used in this work does not target any specific component of the MEA but was designed to impact the two electrodes and the membrane. Material degradations are induced or exacerbated thanks to a relatively high operation temperature $\left(80^{\circ} \mathrm{C}\right)$, load

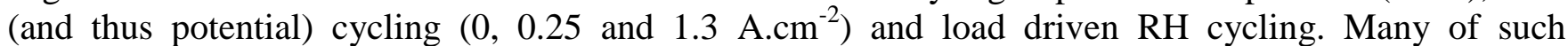
combined stressor AST have been introduced recently in the literature, mostly to evaluate membrane 
durability. Indeed, membranes with a reinforcement matrix (such as expanded polytetrafluoroethylene ePTFE-) are much more robust than the previous generation of materials [3, 25-27]. Such AST are expected to significantly accelerate the membrane failure [28, 29] $v s$ the usual OCV test suggested by the U.S. department of energy (DOE) [3]. Another advantage of combined stressor-AST is their ability to induce high mechanical stress via fast cycling of membrane hydration through load variation instead of gas RH variation [30]. In our case, the protocol consists of keeping the gas inlet RH to a relatively low value (i.e. 50\%) and holding the air and hydrogen flow constant (i.e. to the values required for the highest current density), while cycling the FC load. Thus, humidity cycles of the membrane -and ionomer in the electrodes- are induced entirely by current cycling, while the other operation parameters such as gas flow rates, dew point, and pressures can remain unchanged during the whole cycle. In addition, potential cycling can be performed -almost- independently of RH cycling by adjusting the duration of low and high current sequences, as explained in the following. Figure 2 shows the current density and voltage profiles during an elementary sequence (105 s) of the AST used in this work: 19 load cycles are performed during a hydration/dehydration cycle. Two extreme cases can be derived from this protocol:

- The number of load cycles can be decreased so that a hydration/dehydration cycle corresponds to one load cycle only. This would correspond to a humidity cycling protocol.

- Conversely, the load cycling can be performed so fast (alternating high and low current density every few seconds for instance) so that one can consider that there is no significant change in the membrane hydration, which would correspond to a pure load/potential cycling protocol.

Such alternative AST will be considered in a future work to better understand, and decorrelate, the impact of load cycling and humidity cycling on material aging. For this work, the AST depicted in Figure 2 consisted in 15634 load cycling sequences and 823 humidity cycling sequences every 24 hours. At Beginning of Life (BoL), the FC voltage reached ca. $0.8 \mathrm{~V}$ at $0.25 \mathrm{~A}^{-\mathrm{cm}^{-2}}$ and $0.35 \mathrm{~V}$ at $1.8 \mathrm{~A} . \mathrm{cm}^{-2}$, these values slightly varying depending on the AST performed. The AST sequence was repeated during at least ten days, and a characterization stage was performed every 24 hours to monitor the decrease of the FC performance and to assess material degradation. This characterization stage included:

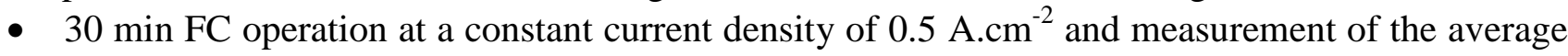
voltage during the last 15 min (as a first indication of the FC performance).

- Measurement of the impedance spectra at $0.5 \mathrm{~A} . \mathrm{cm}^{-2}$, in the conditions mentioned above.

- Measurement of the polarization curve, firstly by increasing the current density -with steps of 60 $\mathrm{s}$, then by decreasing the current density. The average values measured during the last $30 \mathrm{~s}$ of each current step were retained.

- Then the cathode compartment was flushed 10 min with nitrogen and the hydrogen permeation current was measured. The nitrogen flow was stopped and the cathode ECSA was measured, in the conditions mentioned in the previous section.

- Finally, the anode was flushed with nitrogen and hydrogen was introduced at the cathode so that the hydrogen permeation current and the anode ECSA were also assessed. Of course, one did not expect significant differences between the hydrogen permeation current measured on the anode side and on the cathode side.

For comparison with the AST and as a benchmark, the FC was also operated at constant current $(0.5$ A. $\mathrm{cm}^{-2}$ ) during a similar duration (i.e. ten days) with characterization stages performed every 24 hours. 

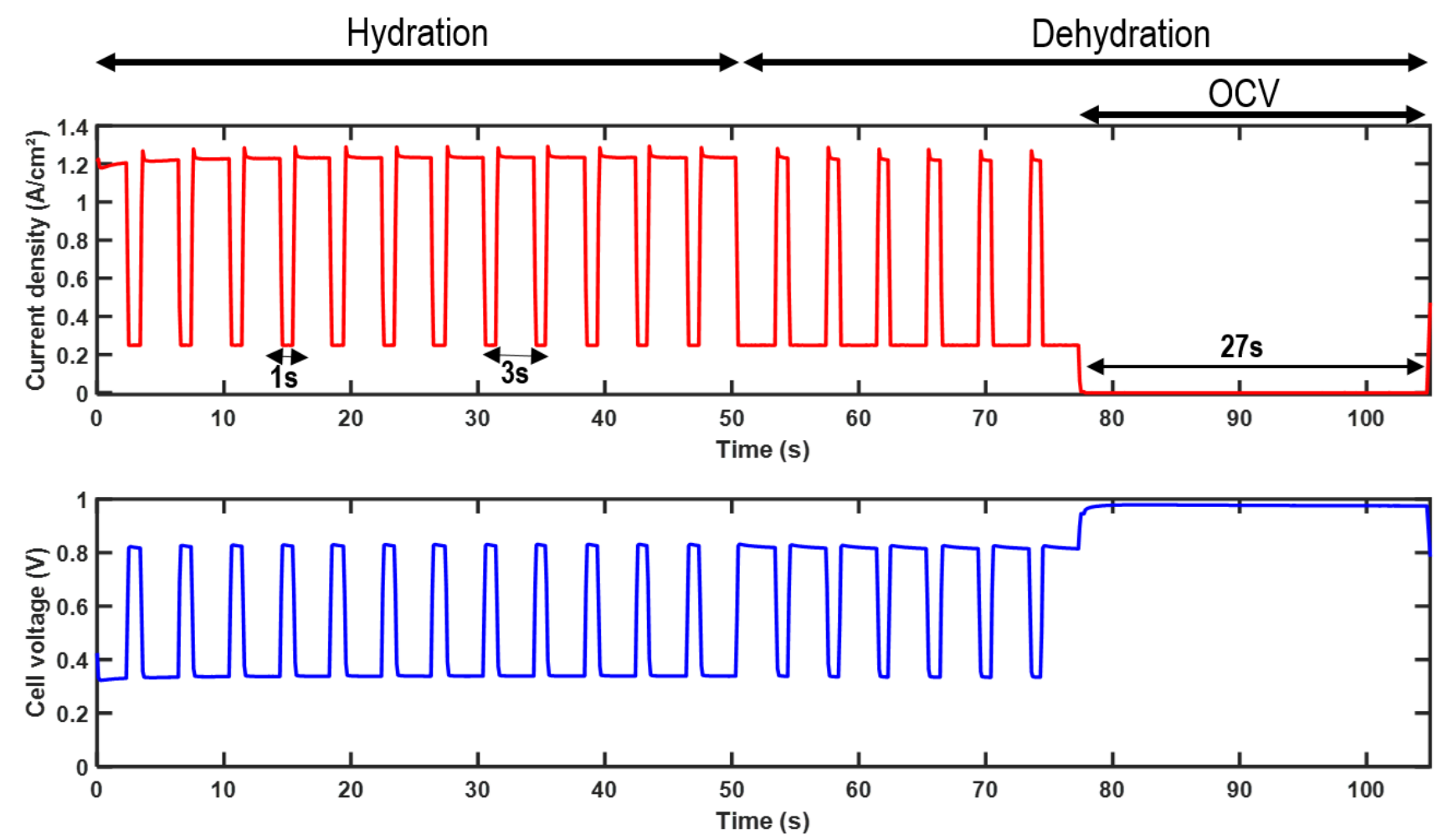

Figure 2. Current density and voltage profiles of the RH and load cycling AST. The hydration stage consists in an alternation of one-second low current $\left(0.25 \mathrm{A.cm}^{-2}\right)$ sequences and three-seconds high current $\left(1.3 \mathrm{~A} . \mathrm{cm}^{-2}\right)$ sequences and lasts $52 \mathrm{~s}$. The dehydration stage consists in $3 \mathrm{~s}$ low current and $1 \mathrm{~s}$ high current sequences followed by $27 \mathrm{~s}$ at $O C V$, which gives a total duration of $105 \mathrm{~s}$.

\section{Electrochemical Impedance Spectroscopy Model}

As mentioned in the introduction, one of the main difficulties with EIS lies in the choice of the impedance model used to interpret the experimental data. This difficulty remains when focusing on the high frequency domain, to dodge the complications linked with oxygen transport in the GDL and gas channels [14-17]. In a previous work [19], we showed that although most of PEMFC impedance spectra can be modelled using the classical Randles Electrical Equivalent Circuit (EEC), this is not possible when a straight line appears at high frequencies. Indeed, the Randles EEC relies on a thin-film representation [31-32] of the cathode, which does not account for its -possible- volumetric feature(s) and necessarily leads to the presence of a vertical tangent to the semi-circle at high frequencies. The volumetric character of the electrode is only taken into account in Transmission Line Models (TLM) [4, 33] or in agglomerate models [34-36], both approaches considering charge and -possibly- mass-transport through the electrode volume. However, it must be kept in mind that TLM do usually not consider masstransport, which means that it is necessary to adapt the EEC, especially at the cathode. With such an adaptation, it can be shown that modified TLM-like EEC are a more general representation of the electrode than Randles-like EEC: their impedance approaches that of a Randles EEC when the ion transport resistance through the catalyst layer becomes negligible compared to the ORR kinetics parameters, i.e. the charge-transfer resistance and the double layer capacitance [19]. Nevertheless, this conclusion is true for a single electrode. As shown in the following, other ambiguities may arise when the whole MEA, i.e. the cathode and the anode, has to be considered. 

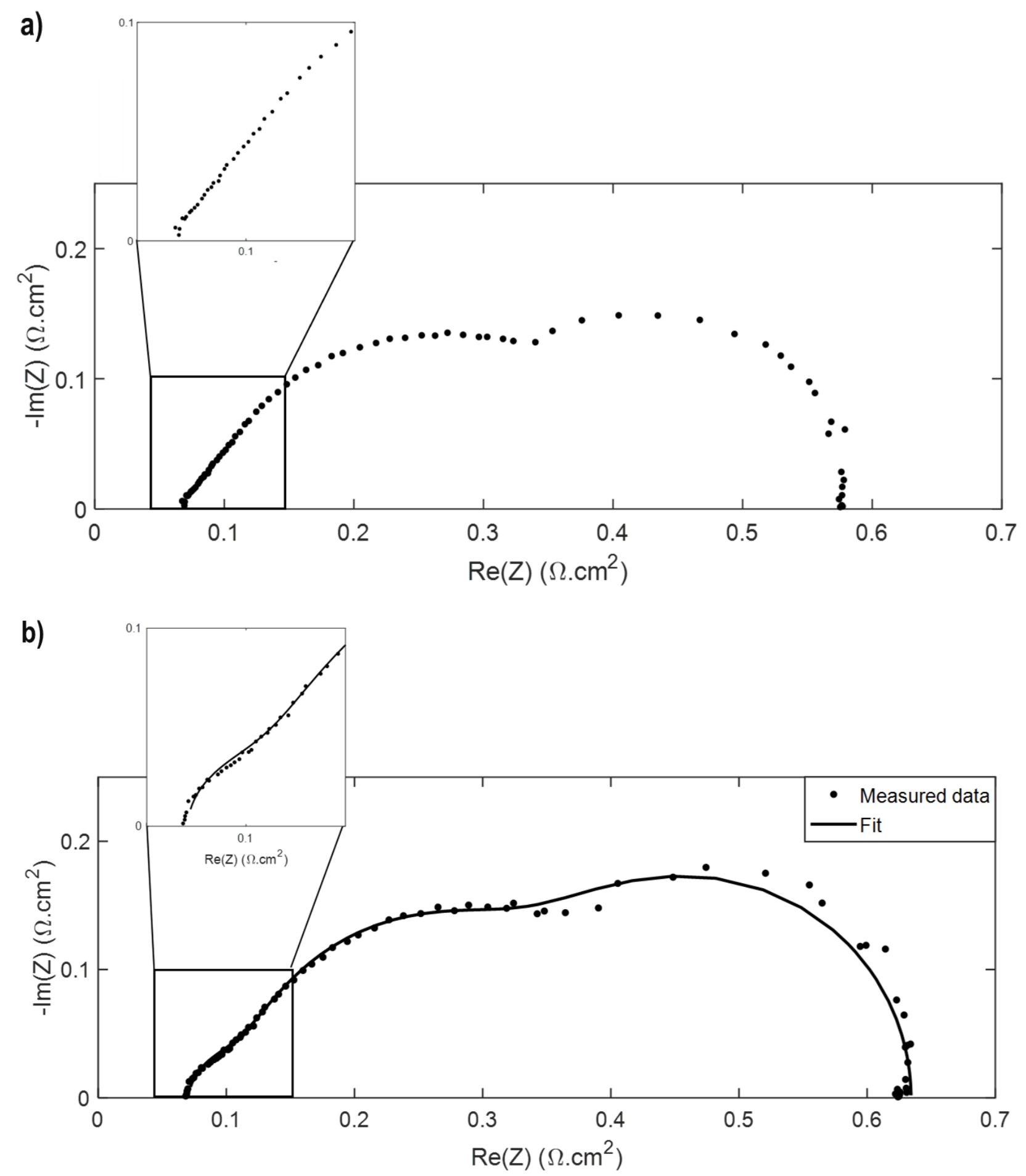

Figure 3. a) Impedance spectra of a pristine MEA measured at $0.5 \mathrm{A.cm}^{-2}$, from $20 \mathrm{mHz}$ to $10 \mathrm{kHz}$. The high/mid frequency semi-circle begins with a straight line that can be modelled either with a TLMlike EEC or with a Randles-like EEC including an anode (cf. Figure 4). The theoretical spectra obtained with these EEC and the parameters given in Table 1 are not shown for clarity. b) Impedance spectra of the same MEA monitored after $240 \mathrm{~h}$ of the ageing protocol application. The EEC used to fit the experimental data is shown in Figure 4c). One can observe a significant growth of the anode HF loop compared to the spectrum of the pristine MEA.

Table 1: Impedunce parameters estimated from the experimental data in Figure $3 a$ with the EEC in Figure 4. $\sigma$ stands for the residuals.

\begin{tabular}{|c|c|c|c|c|c|c|c|c|}
\hline EEC & $\begin{array}{l}\boldsymbol{R}_{\mathbf{h f}} \\
\left(\Omega . \mathrm{cm}^{2}\right)\end{array}$ & $\begin{array}{l}\boldsymbol{\tau} \\
(\mathrm{s})\end{array}$ & $\begin{array}{l}\boldsymbol{R}_{\mathbf{d}} \\
\left(\Omega . \mathrm{cm}^{2}\right)\end{array}$ & $\begin{array}{l}\boldsymbol{R}_{\text {ion }} \\
\left(\Omega . \mathrm{cm}^{2}\right)\end{array}$ & $\begin{array}{l}C_{\mathrm{dl}, \mathrm{c}} \\
\left(\Omega . \mathrm{cm}^{-2}\right)\end{array}$ & $\begin{array}{l}\boldsymbol{R}_{\text {ct,c }} \\
\left(\Omega . \mathrm{cm}^{2}\right)\end{array}$ & $\begin{array}{l}C_{\mathrm{dl}, \mathrm{a}} \\
\left(\Omega . \mathrm{cm}^{-2}\right)\end{array}$ & $\begin{array}{l}\boldsymbol{R}_{\mathrm{ct}, \mathrm{a}} \\
\left(\Omega . \mathrm{cm}^{2}\right)\end{array}$ \\
\hline $\begin{array}{l}\text { Randles } \\
\sigma=7.6 \times 10^{-3}\end{array}$ & 0.0816 & 0.121 & 0.290 & - & 0.0146 & 0.209 & - & - \\
\hline
\end{tabular}




\begin{tabular}{|l|l|l|l|l|l|l|l|l|}
\hline $\begin{array}{l}\text { TLM } \\
\sigma=3.0 \times 10^{-3}\end{array}$ & 0.0570 & 0.127 & 0.2670 & 0.1315 & 0.0184 & 0.214 & - & - \\
\hline $\begin{array}{l}\text { Randles }+ \text { anode } \\
\sigma=1.8 \times 10^{-3}\end{array}$ & 0.0717 & 0.128 & 0.263 & - & 0.0196 & 0.213 & 0.0109 & 0.0338 \\
\hline
\end{tabular}

Figure 3a shows the impedance spectrum of a pristine MEA measured at $0.5 \mathrm{~A} . \mathrm{cm}^{-2}$, from $20 \mathrm{mHz}$ to 10 $\mathrm{kHz}$. The straight line that appears at high frequencies seems to indicate that a TLM-like model would be more adapted than a Randles EEC to fit the experimental data, which is apparently confirmed by the residuals in Table 1. Nevertheless, we obtained a better fit using a Randles EEC that was slightly modified by adding a charge-transfer resistance and a double-layer capacity (in parallel) in series with the cathode. These additional components stand for the anode, where hydrogen mass-transport is usually negligible, which justifies the absence of a Warburg element in this electrode. The three EEC (Randles, TLM, and Randles+ anode) are depicted in Figure 4. It must also be noted that increasing the complexity of the model by using for instance a TLM EEC in series with an anode charge-transfer resistance and double-layer capacity (in an attempt to take the best of the three EEC) or constant phase elements instead of capacities does not lead to a significant improvement of the residuals.

a)

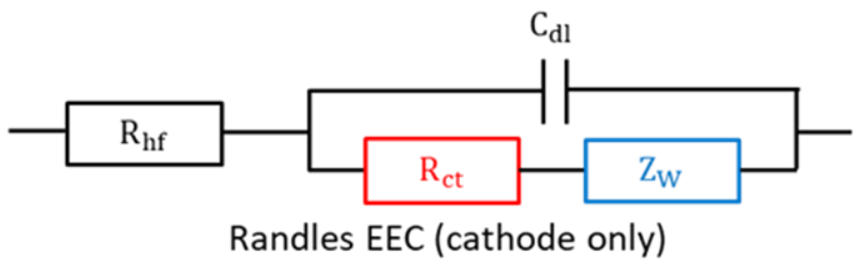

b)

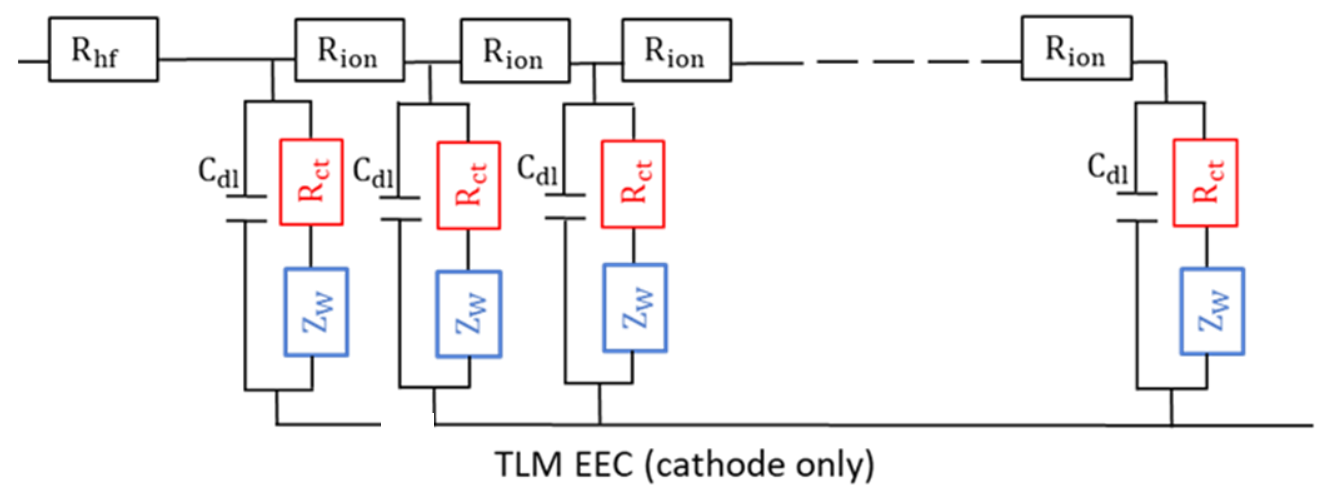

c)

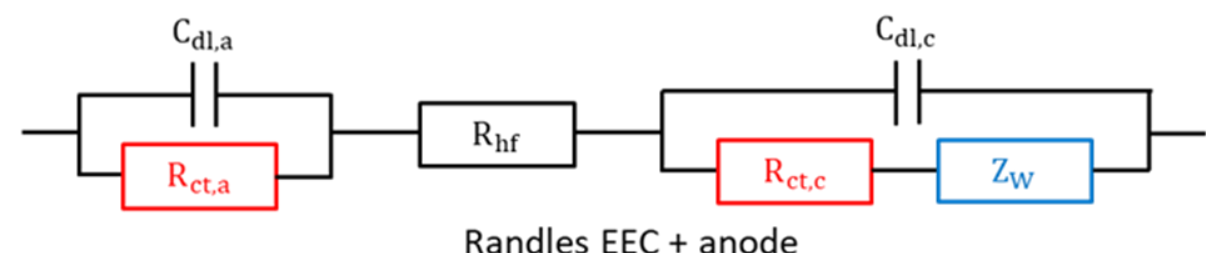

Figure 4. Randles (a), TLM [31] (b) and modified Randles (c) EEC used to fit the experimental data of Figure 3. Only the modified Randles EEC includes the anode kinetics parameters (double-layer capacity and charge-transfer resistance). During the AST, the best fit with the experimental data was obtained when considering the anode in series with the Randles circuit (c). In all cases, the Warburg impedance $Z_{W}$ connected in series to $R_{c t}$ in the cathode accounts for oxygen transport limitations within the catalyst layer.

\section{Anode ageing}

Results presented in the last section show that the impedance of the anode can easily be mistaken with a $45^{\circ} \mathrm{HF}$ straight line typical of potential diffusion through the cathode thickness: in terms of quality of fit, to this point, these two approaches were very similar. Nevertheless, considering the anode in the EEC became more relevant when performing the AST described in Figure 2. One can observe in Figure $3 \mathrm{~b}$ that the anode HF loop grew significantly during the test, along with the intermediate and low frequency loops, which denotes a degradation of both electrodes. The evolution of the model parameters estimated from the experimental data using the EEC of Figure $4 \mathrm{c}\left(R_{\mathrm{ct}, \mathrm{a}}, C_{\mathrm{dl}, \mathrm{a}}, R_{\mathrm{ct}, \mathrm{c}}, C_{\mathrm{dl}, \mathrm{c}}, R_{\mathrm{hf}}, R_{d}\right.$ and $\left.\tau\right)$ is shown in Table 2. One can observe an increase in the charge-transfer resistance and a decrease in the double-layer capacity at the anode and the cathode, which is consistent with the evolution of the impedance spectra. Degradations on the cathode side also impact the diffusion resistance $R_{\mathrm{d}}$. 
A first way to confirm these tendencies was to compare the evolution of the impedance parameters with those observed when the FC was operated at constant current (i.e. $0.5 \mathrm{~A} . \mathrm{cm}^{-2}$ ). These evolutions are plotted in Figure 5 and one can clearly see that, while the impedance parameters tend to degrade during the AST, they tend to improve when the FC was operated at constant current (except for the cathode double-layer capacity). One can also observe a two-step evolution of the impedance parameters during the AST, with a clear change in behavior after about $120 \mathrm{~h}$ : the degradation of the anode parameters $R_{\mathrm{ct}, \mathrm{a}}, C_{\mathrm{dl}, \mathrm{a}}$, for instance, became much more significant during the second half of the aging test. However, these results are to be regarded from a qualitative point of view, because of possible correlations or cross-correlations between the impedance parameters [37]. This is particularly true for the decrease of the anode and cathode double-layer capacities, which should probably be considered as a whole: their sum tends to decrease but it may be delicate to separate the role of each electrode when they are both impacted by the AST. In general, one should be able to confirm the evolution of the impedance by monitoring other parameters.

Table 2. Evolution of the impedance parameter during the AST (Figure 2). Their identification was made starting from EEC $c$ in Figure 4. (Some of the values identified after 24 hours are not consistent with the others due to a temporary malfunction of the test bench.)

\begin{tabular}{|l|l|l|l|l|l|l|l|}
\hline Time & $\begin{array}{l}\boldsymbol{R}_{\text {hf }} \\
\left(\Omega . \mathrm{cm}^{2}\right)\end{array}$ & $\begin{array}{l}\boldsymbol{\tau} \\
(\mathrm{s})\end{array}$ & $\begin{array}{l}\boldsymbol{R}_{\mathbf{d}} \\
\left(\Omega . \mathrm{cm}^{2}\right)\end{array}$ & $\begin{array}{l}\boldsymbol{C}_{\text {dl,cc }} \\
\left(\Omega . \mathrm{cm}^{-2}\right)\end{array}$ & $\begin{array}{l}\boldsymbol{R}_{\text {ct,c }} \\
\left(\Omega . \mathrm{cm}^{2}\right)\end{array}$ & $\begin{array}{l}\boldsymbol{C}_{\text {dl,a }} \\
\left(\Omega . \mathrm{cm}^{-2}\right)\end{array}$ & $\begin{array}{l}\boldsymbol{R}_{\text {ct,a }} \\
\left(\Omega . \mathrm{cm}^{2}\right)\end{array}$ \\
\hline $\mathbf{B o L}$ & 0.0717 & 0.128 & 0.263 & 0.0196 & 0.213 & 0.0109 & 0.0338 \\
\hline $\mathbf{2 4 ~ h}$ & 0.0674 & 0.267 & 0.506 & 0.0186 & 0.242 & 0.0139 & 0.0254 \\
\hline $\mathbf{4 8 ~ h}$ & 0.0634 & 0.175 & 0.248 & 0.0199 & 0.191 & 0.0151 & 0.0296 \\
\hline $\mathbf{7 2} \mathbf{~ h}$ & 0.0643 & 0.151 & 0.252 & 0.0203 & 0.192 & 0.0172 & 0.0290 \\
\hline $\mathbf{9 6} \mathbf{~ h}$ & 0.0632 & 0.149 & 0.289 & 0.0207 & 0.199 & 0.0146 & 0.0272 \\
\hline $\mathbf{1 2 0} \mathbf{~ h}$ & 0.0646 & 0.137 & 0.295 & 0.0218 & 0.205 & 0.0153 & 0.0254 \\
\hline $\mathbf{1 4 4} \mathbf{~ h}$ & 0.0650 & 0.124 & 0.291 & 0.0220 & 0.196 & 0.0141 & 0.0252 \\
\hline $\mathbf{1 6 8} \mathbf{~ h}$ & 0.0661 & 0.117 & 0.281 & 0.0215 & 0.200 & 0.0098 & 0.0298 \\
\hline $\mathbf{1 9 2} \mathbf{~ h}$ & 0.0688 & 0.114 & 0.304 & 0.02010 & 0.223 & 0.0077 & 0.0383 \\
\hline $\mathbf{2 1 6} \mathbf{~ h}$ & 0.0720 & 0.112 & 0.294 & 0.0190. & 0.224 & 0.0062 & 0.0442 \\
\hline $\mathbf{2 4 0} \mathbf{~ h}$ & 0.0728 & 0.114 & 0.325 & 0.0179 & 0.250 & 0.0051 & 0.0555 \\
\hline
\end{tabular}

As expected, the degradation of the FC impedance parameters is accompanied by a strong diminution of its performance. Figure 6 (top) makes it possible to compare the evolution of the FC voltage at 0.5 A.cm ${ }^{-2}$ during the AST and when the FC is operated in steady state. On the one hand, the values at BoL were close to each other and the cell voltage decreased only sparsely during the constant current test ($64 \mu \mathrm{V} . \mathrm{h}^{-1}$, i.e. $-2 \%$ over $240 \mathrm{~h}$ ). On the other hand, the decay was much more pronounced during the AST $\left(-940 \mu \mathrm{V} \cdot \mathrm{h}^{-1}\right.$, i.e. $-33 \%$ over $\left.240 \mathrm{~h}\right)$. In addition, the degradation of the performance was rather homogeneous over the whole polarization curve in the case of the AST (Figure 6, bottom left), while a small improvement at high current density was observed during the constant current test (Figure 6, bottom right). The evolution of the local polarization curves (i.e. FC voltage $v s$ local currents) measured independently on each of the 20 segments showed a relatively homogeneous drop the performance along the flow field plates (Figure 7). However, this does not mean that the degradation mechanisms were strictly identical everywhere. This point will be clarified in a next paper, in which physical analyses of the used MEA components will be emphasized.

The decrease of the cathode and anode ECSA seemed also rather homogeneous along the flow field plates, although significant dispersion in the local values were monitored, preventing definitive conclusions on this matter. For clarity, Figure 8 shows the cathode and anode ECSA averaged over the MEA area. Like the impedance parameters, a two-step evolution is observed, with a clear shift in the slope of the interpolation lines after $120 \mathrm{~h}$. More specifically, the anode ECSA did not evolve significantly during the first half of the protocol but dropped dramatically afterwards. Conversely, the cathode ECSA seemed to decrease much faster during the first $120 \mathrm{~h}$ than during the second half. Interestingly, this behavior does not match perfectly that of the impedance parameters, since an increase of the cathode charge-transfer resistance was observed only during the second half of the protocol (the charge-transfer resistance even decreased during the first $120 \mathrm{~h}$ ). Nevertheless, this is the only concrete divergence we noticed between the evolution of the ECSA and those of the impedance parameters: the growth of the anode HF loop that was detected thanks to EIS was totally confirmed by the measurements of the anode ECSA. 




- Constant current test

- Accelerated stress test
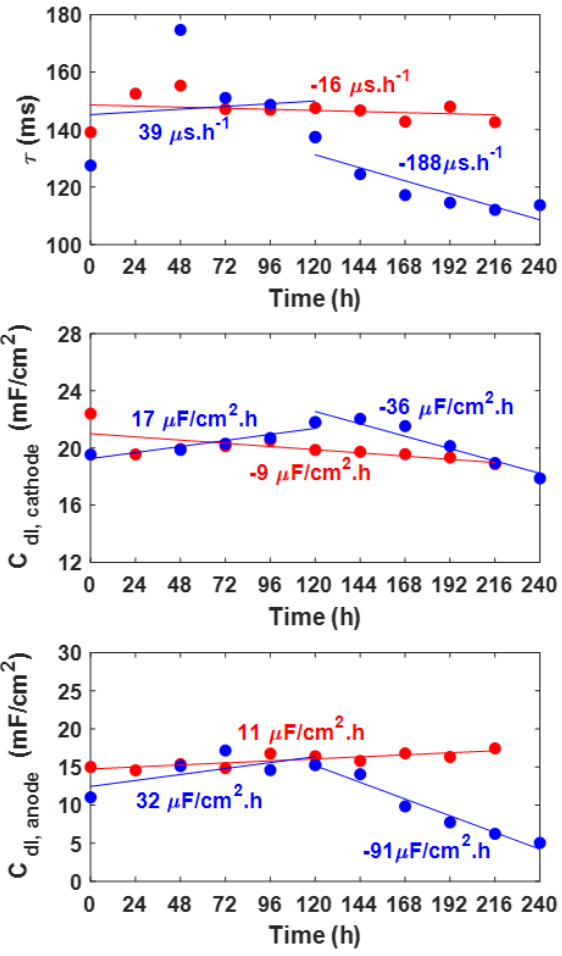
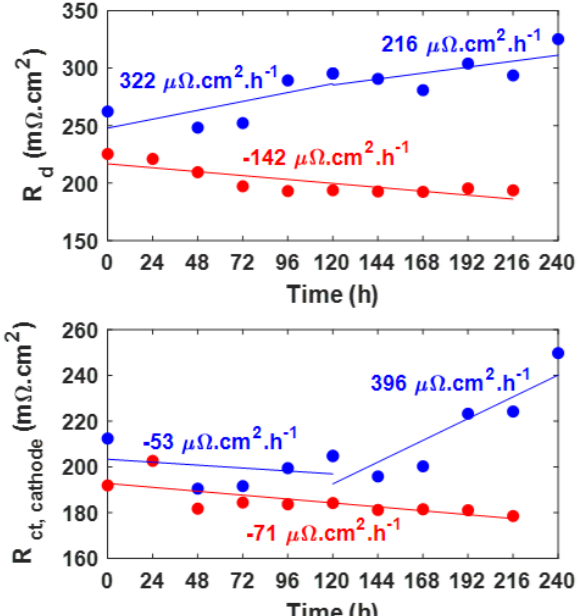
Time (h)

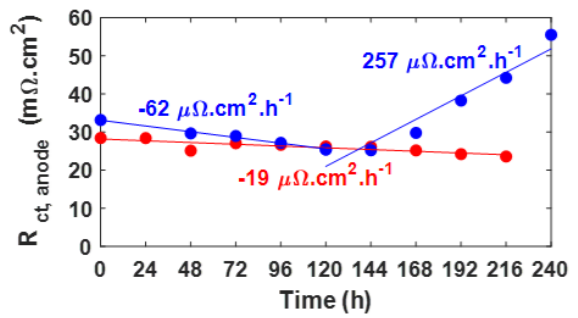

Figure 5. Evolution of the impedance parameters during the AST and comparison with those obtained when the FC was operated at constant current $\left(0.5 \mathrm{~A} . \mathrm{cm}^{-2}\right)$. All parameters degraded during the AST, although the changes were significant only after $120 \mathrm{~h}$ of operation (values identified after $24 \mathrm{~h}$ during the AST are not plotted. See Table 2).
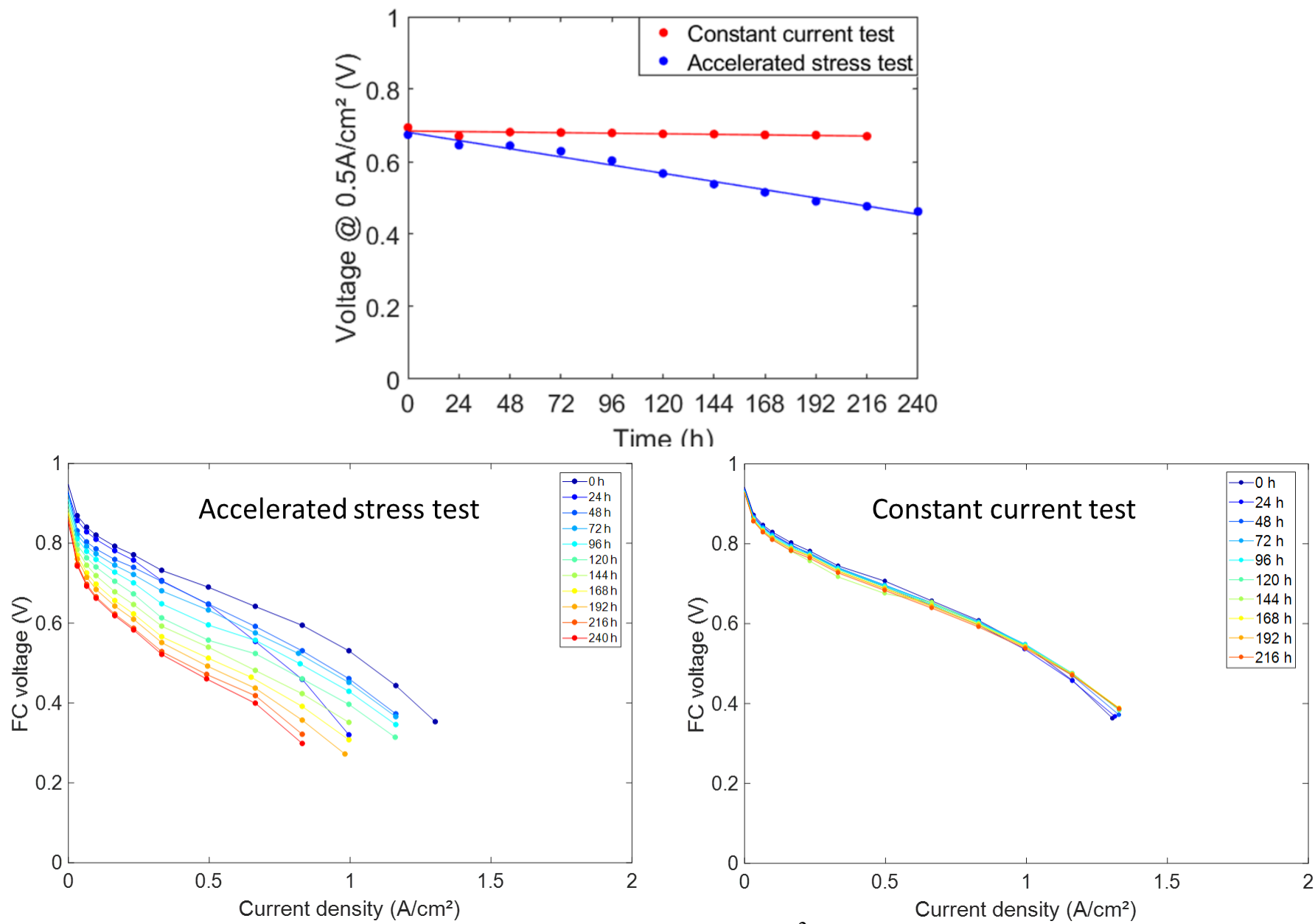

Figure 6. Top: evolution of the FC voltage at $0.5 \mathrm{A.cm}^{-2}$ during the AST and for steady-state operation. From the linear interpolation of the data, the voltage decreased by $64 \mu V \cdot h^{-1}$ during the constant current protocol and by $940 \mu V . h^{-1}$ during the AST. All values were measured during the 
characterization stage performed every $24 \mathrm{~h}$. Bottom: evolution of the FC polarization curve during the AST (left) and, for comparison, during the constant current test (right). The degradation of the performance was quite homogeneous over the whole of the operation domain (values measured after 24 $h$ are not consistent with the others due to a temporary malfunction of the test bench).
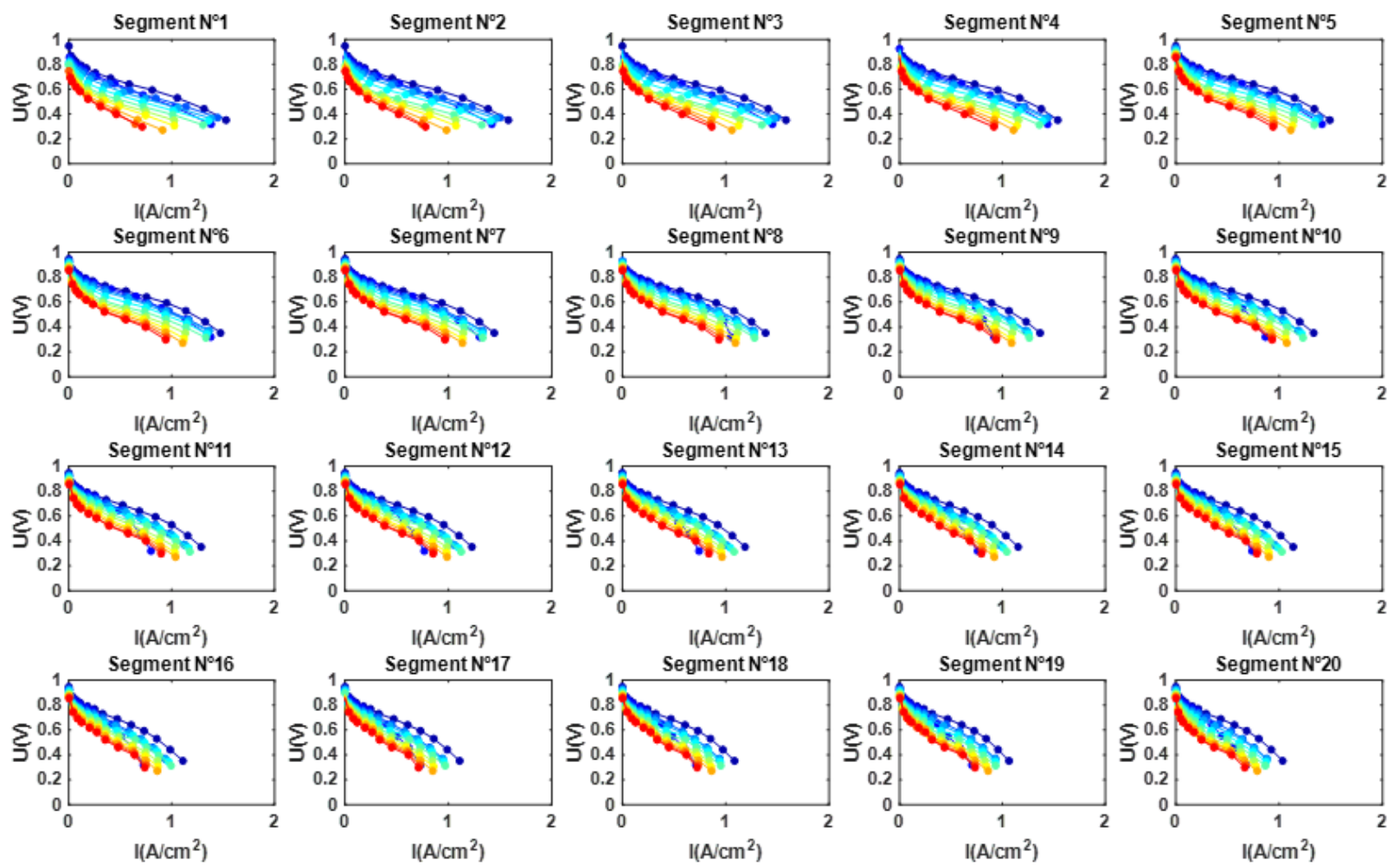

Figure 7. Evolution of the local polarization curves (i.e. FC voltage vs. local currents) measured independently on each of the 20 segments. A relatively homogeneous drop the performance along the flow field plates can be observed.


Figure 8. Averaged cathode (left) and anode (right) ECSA during the AST and during steady-state operation. On the one hand, one can clearly see a similar two steps evolution as in the case of the impedance parameters, and a significant drop of the anode ECSA after $120 \mathrm{~h}$ of operation. On the other hand, the rate of the cathode ECSA degradation was slower during the second half of the AST.

\section{Discussion}

Although the experimental data provided by EIS are delicate to interpret, most of the difficulties are linked with the low-frequency-region of the spectra. The high-frequency-domain is more interesting to consider since many of the complications related to oxygen transport (i.e. oscillations of oxygen concentration along the gas channels [14-15] and non-Fickian oxygen diffusion [16-17]) come from phenomena with relatively high characteristic times. Indeed, high frequencies make it possible to consider mostly the electrodes and purely resistive components such as the membrane. In this regard, the 
present data showed that EIS is a reliable tool to monitor the evolution of both the anode and the cathode performances during the AST. The anode was only slightly visible in the impedance spectra at beginning of life, so that they could be fitted with equally-satisfying results using a TLM-like model (without the anode but considering the volumetric character of the cathode) or with a Randles-like model considering both the anode and cathode. Nevertheless, performing an AST made it possible to refine the selection of the EEC and to choose between these two approaches: a significant growth of the anode HF loop was monitored in the course of the test, showing that the EEC must include components of the anode.

Anode degradation has rarely been studied in the literature since most of FC reliability and lifetime issues are linked with the cathode and the membrane [20,21]. To the best of our knowledge, only Schwämmlein et al. showed recently that anode degradation may be significant, but in a very different case than the present one, since their AST consisted in repeated start-up and shut-down sequences [22]. Since the pioneering works of Reiser et al. [38] and the many that followed [13, 21, 23-24, 39-52], startup and shut-down are well-known to induce dramatic local high potential events at the cathode (up to 1.3 or $1.4 \mathrm{~V}$ vs RHE), which entails significant cathode thinning because of carbon corrosion. Although the anode endures also significant potential cycling (typically between $0 \mathrm{~V}$ and $1 \mathrm{~V} v s$ RHE) during start-up and shut-down, anode degradation was not frequently reported, possibly because of its lower impact on FC performances than cathode degradation.

Nevertheless, the AST performed herein did not consist of repeated start-up or shut-down so that the potential cycling sequences were much narrower (hence could be seen as poorly-degrading): typically, between $0 \mathrm{~V}$ and $0.2 \mathrm{~V}$ vs RHE at the anode and between $0.3 \mathrm{~V}$ and $\mathrm{OCV} \approx 1 \mathrm{~V} v s$ RHE at the cathode according to the measurements of individual potential values made $v s$ the hydrogen reference electrodes implemented in the segmented cell. Since carbon corrosion cannot thermodynamically occur at the anode in such potential conditions, the loss of anode ECSA is not due to classical Pt particles detachment induced by the corrosion of the carbon support. As expected, neither did we observe any negative or reverse current during transients. Although the conditions to which the MEA was submitted during the AST were harsh, potential cycling does not seem to be the main origin of anode ageing. Other explanation must be considered, like a possible mechanical destabilization of the anode microstructure under wet-dry cycling. Such phenomena have already been reported but only in the case of ex situ experiments [53]. The elevation of temperature at high current density, known to entail local membrane dehydration (whatever the gas inlet $\mathrm{RH}$ ) [54] may also be one of the factors governing anode aging. Complementary AST protocols will be performed in order to assess the impact of RH and load cycling on the FC performances separately.

Finally, all results presented in this paper have been reproduced at least two times with MEA from the same batch. However, applying a similar AST to MEA made with a different and more robust carbon support at the anode (i.e. Vulcan instead of HSA amorphous carbon) did not lead to any anode degradation issue, which may support the argument of mechanical or thermal effects.

\section{Conclusions and perspectives}

In this paper, the degradations of a PEMFC were investigated by submitting the cell to an accelerated stress test consisting of a complex sequence in which load-induced humidity cycling combined with OCV was involved. The cell operation was closely followed during the test by monitoring various parameters such as FC performance (polarization plots), electrode ECSA, hydrogen permeation and impedance spectra. The results demonstrate that, although initially, the anode may be ignored to model the electrochemical impedance spectroscopy data if one uses a TLM EEC to take into account the behavior of the cathode "porous structure", this is no longer possible after the AST. As such, the present data show that, beyond classical cathode and membrane degradations, the cell undergoes pronounced anode degradations, that significantly affect the cell performances. Local potential measurements showed that the anode (and cathode) degradation of the performances were not linked to severe potential cycling in the present conditions; this is particularly the case for the anode, the potential of which remaining between 0 and $0.2 \mathrm{~V} v s$ RHE over the whole test. This suggests that classical mechanisms of $\mathrm{Pt} / \mathrm{C}$ degradation at the anode must not be at stake here, and alternatively, it is proposed that mechanical destabilization of the anode microstructure under wet-dry cycling is occurring. The elevation of temperature at high current density, known to entail local membrane dehydration (whatever the gas inlet RH) may be an aggravating factor of the anode aging.

In the near future, we are going to investigate the anode degradation mechanisms by performing post mortem physico-chemical analyses of aged MEA and by introducing some modifications in the AST to clearly identify which conditions (RH cycling or load cycling, or both combined) are the most 
detrimental to the cell performances and damaging to its constitutive materials.

\section{Acknowledgements}

The authors would like to thank the French National Research Agency (ANR, project ANR-17-CE050016) and the Agency for Environment, Energy and Sustainable Development (ADEME) for the support to this work.

\section{References}

1. U.S.DOE, Multi-Year Res. Dev. Demonstr. Plan, Chapter 3.4 Fuel Cells, (2017), https://www.energy.gov/sites/prod/files/2017/05/f34/fcto_myrdd_fuel_cells.pdf.

2. X-Z. Yuan, H. Li, S. Zhang, J. Martin, H. Wang, A review of polymer electrolyte membrane fuel cell durability test protocols, J. Power Sources, Vol. 196, pp. 9107-9116, 2011.

3. C. Lim, L. Ghassemzadeh, F. Van Hove, M. Lauritzen, J. Kolodziej, G.G. Wang, S. Holdcroft, E. Kjeang, J. Power Sources Vol. 257, pp. 102-110, 2014.

4. T. Gaumont, G. Maranzana, O. Lottin, J. Dillet, S. Didierjean, J. Pauchet, L. Guetaz, Measurement of protonic resistance of catalyst layers as a tool for degradation monitoring, Int. J. Hydrogen Energy, Vol. 42, pp. 1800-1812, 2017.

5. R.L. Borup, J.R. Davey, F.H. Garzon, D.L. Wood, M.A. Inbody, PEM fuel cell electrocatalyst durability measurements, J. Power Sources, Vol. 163, pp. 76-81, 2006.

6. R. Lin, B. Li, Y.P. Hou, J.M. Ma, Investigation of dynamic driving cycle effect on performance degradation and micro-structure change of PEM fuel cell, Int. J. Hydrogen Energy, Vol. 34, pp. 2369-2376, 2009.

7. S.J. Bae, S.-J. Kim, J.I. Park, C.W. Park, J-H. Lee, I. Song, N. Lee, Ki-B. Kim, J-Y. Park, Lifetime prediction of a polymer electrolyte membrane fuel cell via an accelerated startup-shutdown cycle test, Int. J. Hydrogen Energy, Vol. 37, pp. 9775-9781, 2012.

8. S. Abbou, J. Dillet, G. Maranzana, S. Didierjean, O. Lottin, Local potential evolutions during proton exchange membrane fuel cell operation with dead-ended anode - Part I: Impact of water diffusion and nitrogen crossover, J. Power Sources, Vol. 340, pp. 337-346, 2017.

9. S. Abbou, J. Dillet, G. Maranzana, S. Didierjean, O. Lottin, Local potential evolutions during proton exchange membrane fuel cell operation with dead-ended anode - Part II: Aging mitigation strategies based on water management and nitrogen crossover, J. Power Sources, Vol. 340, pp. 419427, 2017.

10. R. Petrone, D. Hissel, M.C. Pera, D. Chamagne, R. Gouriveau, Accelerated stress test procedures for PEM fuel cells under actual load constraints: state-of-the-art and proposals, Int. J. Hydrogen Energy, Vol. 40, pp. 12489-12505, 2015.

11. S. Zhang, X. Yuan, H. Wang, W. Mérida, H. Zhu, J. Shen, S. Wu, J. Zhang, A review of accelerated stress tests of MEA durability in PEM fuel cells, Int. J. Hydrogen Energy, Vol. 34, pp. 388-404, 2009.

12. L. Dubau, L. Castanheira F. Maillard M. Chatenet O. Lottin G. Maranzana, J. Dillet, A. Lamibrac, J.-C. Perrin, E. Moukheiber, A. Elkaddouri, G. De Moor, C. Bas, L. Flandin, N. Caque, A review of PEM fuel cell durability: materials degradation, local heterogeneities of aging and possible mitigation strategies, Wiley Interdisciplinary Reviews: Energy and Environment, Vol. 3, pp. 540$560,2014$.

13. J. Durst, A. Lamibrac, F. Charlot, J. Dillet, L. F. Castanheira, G. Maranzana, L. Dubau, F. Maillard, M. Chatenet, O. Lottin, Degradation heterogeneities induced by repetitive start/stop events in Proton Exchange Membrane Fuel Cell: Inlet vs. Outlet and Channel vs. Land, Applied Catalysis B: Environmental, Vol. 138-139, pp. 416-426, 2013.

14. I.A. Schneider, D. Kramer, A. Wokaun, G.G. Scherer, Oscillations in Gas Channels Part II. Unraveling the Characteristics of the Low Frequency Loop in Air-Fed PEFC Impedance Spectra, J. Electrochem. Soc., Vol. 154(8), B770-B782, 2007.

15. G. Maranzana, J. Mainka, O. Lottin, J. Dillet, A. Lamibrac, A. Thomas, S. Didierjean, A proton exchange membrane fuel cell impedance model taking into account convection along the air channel: on the bias between the low frequency limit of the impedance and the slope of polarization curve, Electrochim. Acta, Vol. 83, pp. 13-27, 2012. 
16. T.E. Springer, T.A. Zawodzinski, S. Gottesfeld, Polymer electrolyte fuel cell model, J. Electrochem. Soc., Vol. 138 (8), pp. 2334-2342, 1991.

17. O. Lottin, B. Antoine, T. Colinart, S. Didierjean, G. Maranzana, C. Moyne, J. Ramousse, Modelling of the operation of Polymer Exchange Membrane Fuel Cells in the presence of electrodes flooding, Int. J. Therm. Sci., Vol. 48, pp. 133-145, 2009.

18. J. Mainka, G. Maranzana, A. Thomas, J. Dillet, S. Didierjean, O. Lottin, One-dimensional Model of Oxygen Transport Impedance Accounting for Convection Perpendicular to the Electrode, Fuel Cells, Vol. 12(5), pp. 848-861, 2012.

19. S. Touhami, J. Mainka, J. Dillet, S. Ait Hammou Taleb, O. Lottin, Transmission Line Impedance Models Considering Oxygen Transport Limitations in Polymer Electrolyte Membrane Fuel Cells, J. Electrochem. Soc., Vol. 166 (15), F1209-F1217, 2019.

20. E. Guilminot, A. Corcella, F. Charlot, F. Maillard, M. Chatenet, Detection of Ptz+ ions and Pt nanoparticles inside the membrane of a used PEMFC. J. Electrochem. Soc., Vol. 154, B96-B105, 2007.

21. E. Guilminot, A. Corcella, M. Chatenet, F. Maillard, F. Charlot, G. Berthome, C. Iojoiu, J.-Y. Sanchez, E. Rossinot, E. Claude, Membrane and Active Layer Degradation upon PEMFC SteadyState Operation. J. Electrochem. Soc., Vol. 154, B1106-B1114, 2007.

22. J. N. Schwämmlein, P. J. Rheinländer, Y. Chen, K. T. Freyer, H. A. Gasteiger, Anode Aging during PEMFC Start-Up and Shut-Down: $\mathrm{H}_{2}$-Air Fronts vs Voltage Cycles, J. Electrochem. Soc., Vol. 165 (16), F1312-F1322, 2018.

23. S. Abbou, J. Dillet, D. Spernjak, R. Mukundan, R. L. Borup, G. Maranzana, O. Lottin, J. Electrochem. Soc., Vol. 162(10), pp. F1212-F1220, 2015.

24. O. Lottin, J. Dillet, G. Maranzana, S. Abbou, S. Didierjean, A. Lamibrac, R. L. Borup, R. Mukundan, D. Spernjak, ECS Transactions, Vol. 69 (17), pp. 1065-1074, 2015

25. S. Venkatesan, C. Lim, S. Holdcroft, and E. Kjeang, J. Electrochem Soc., Vol. 163, F637, 2016.

26. A. Sadeghi Alavijeh, M.-A. Goulet, R. M. H. Khorasany, J. Ghataurah, C. Lim, M. Lauritzen, E. Kjeang, G. G. Wang, and R. K. N. D. Rajapakse, Fuel Cells, Vol. 15, pp. 204, 2015.

27. S. Venkatesan, C. Lim, E. Rogers, S. Holdcroft, and E. Kjeang, Phys. Chem. Chem. Phys., Vol. 17, $13872,2015$.

28. C. S. Gittleman, F. D. Coms, and Y.-H. Lai, In Polymer Electrolyte Fuel Cell Degradation, M. Matthew, K. E. Caglan, and T. N. Veziroglu, Editors, p. 15, Academic Press, Boston, 2012.

29. Y.-H. Lai and G. W. Fly, J. Power Sources, Vol. 274, 1162, 2015.

30. Y.-H. Lai, K. M. Rahmoeller, J. H. Hurst, R. S. Kukreja, M. Atwan, A. J. Maslyn, and C. S. Gittleman, Accelerated Stress Testing of Fuel Cell Membranes Subjected to Combined Mechanical/Chemical Stressors and Cerium Migration, J. Electrochem. Soc., Vol. 165 (6), F3217F3229, 2018.

31. T. Berning and N. Djilali, A 3D, multiphase, multicomponent model of the cathode and anode of a PEM fuel cell, J. Electrochem. Soc., Vol. 150(12), A1589-A1598, 2003.

32. U. Pasaogullari and C.-Y. Wang, Two-phase transport and the role of micro-porous layer in polymer electrolyte fuel cells, J. Electrochem. Soc., Vol. 151(3), A399-A406, 2004.

33. P. M. Gomadam et J. W. Weidner, Analysis of electrochemical impedance spectroscopy in proton exchange membrane fuel cells, Int. J. Energ. Res., Vol. 29 (12), pp. 1133-1151, 2005.

34. M. Bautista, Y. Bultel, P. Ozil, Polymer electrolyte membrane fuel cell modelling: d.c. and a.c. solutions, Chem. Eng. Res. Des., Vol. 82(7), pp. 907-917, 2004.

35. J. Deseure, Coupling RTD and EIS modelling to characterize operating non-uniformities on PEM cathodes, J. Power Sources, Vol. 178, pp. 323-333, 2008.

36. S. Chupin, T. Colinart, S. Didierjean, Y. Dubé, K. Agbossou, G. Maranzana, O. Lottin, Numerical investigation on the impact of gas and cooling flow configurations on current and water distributions in a polymer membrane fuel cell through a pseudo-two-dimensional diphasic model, J. Power Sources, Vol. 19516), pp. 5213-5227, 2010.

37. J. Mainka, G. Maranzana, J. Dillet, S. Didierjean, O. Lottin, On the Estimation of High Frequency Parameters of PEM Fuel Cells via Electrochemical Impedance Spectroscopy (EIS), J. Power Sources, Vol. 253, pp 381-391, 2014.

38. C. A. Reiser, L. Bregoli, T. W. Patterson, J. S. Yi, J. D. Yang, M. L. Perry, T. D. Jarvi, Electrochem. Solid-State Lett., Vol. 8, A273, 2005. 
39. G. Maranzana, A. Lamibrac, J. Dillet, S. Abbou, S. Didierjean, O. Lottin, Startup (and Shutdown) model for Polymer Electrolyte Membrane Fuel Cells, J. Electrochem. Soc., Vol. 162(7), pp. F694F706, 2015.

40. Z. Siroma, N. Fujiwara, T. Ioroi, S.-I. Yamazaki, H. Senoh, K. Yasuda, K. Tanimoto, Transient phenomena in a PEMFC during the start-up of gas feeding observed with a 97-fold segmented cell, Journal of Power Sources, Vol. 172, pp. 155-162, 2007.

41. Q. Shen, M. Hou, D. Liang, Z. Zhou, X. Li, Z. Shao, B. Yi, Study on the processes of start-up and shutdown in proton exchange membrane fuel cells, J. Power Sources, Vol. 189, pp. 1114-1119, 2009.

42. A. Ofstad, J. Davey, S. Sunde, R. L. Borup, Carbon Corrosion of a PEMFC During Shutdown/Start-up when Using an Air Purge Procedure, ECS Transactions, Vol. 16 (2), pp. 1301-1311, 2008.

43. N. Linse, G. G. Scherer, A. Wokaun, L. Gubler, Start/Stop Induced Carbon Corrosion in Polymer Electrolyte Fuel Cells, ECS Transactions, Vol. 25 (1), pp. 1849-1859, 2009.

44. J. Dillet, D. Spernjak, A. Lamibrac, G. Maranzana, R. Mukundan, J. Fairweather, S. Didierjean, R. L. Borup, O. Lottin, Impact of flow rates and electrode specifications on degradations during repeated startups and shutdowns in polymer-electrolyte membrane fuel cells, J. Power Sources, Vol. 250, pp. 68-79, 2014.

45. S. Komini Babu, D. Spernjak, J. Dillet, A. Lamibrac, G. Maranzana, S. Didierjean, O. Lottin, R.L. Borup, R. Mukundan, Spatially resolved degradation during startup and shutdown in polymer electrolyte membrane fuel cell operation, Applied Energy, Vol. 254, 113659, 2019.

46. Y. Yu, Z. Tu, H. Zhang, Z. Zhan, and M. Pan, Comparison of degradation behaviors for open-ended and closed proton exchange membrane fuel cells during startup and shutdown cycles, J. Power Sources, Vol. 196, 5077, 2011.

47. T. Mittermeier, A.Weiß, F. Hasch’e, G. Hübner, and H. A. Gasteiger, PEM Fuel Cell Start-up/Shutdown Losses vs Temperature for Non-Graphitized and Graphitized Cathode Carbon Supports, J. Electrochem. Soc., Vol. 164, F127, 2017.

48. J. H. Kim, E. A. Cho, J. H. Jang,H. J. Kim, T. H. Lim, I. H.Oh, J. J.Ko, and S. C. Oh, Effects of Cathode Inlet Relative Humidity on PEMFC Durability during Startup-Shutdown Cycling: I. Electrochemical Study, J. Electrochem. Soc., Vol. 157, B104, 2010.

49. J. H. Kim, Y. Yeon Jo, E. A. Cho, J. H. Jang, H. J. Kim, T.-H. Lim, I.-H. Oh, J. J. Ko, and I. J. Son, Effects of Cathode Inlet Relative Humidity on PEMFC Durability during Startup-Shutdown Cycling: II. Diagnostic Study, J. Electrochem. Soc., Vol. 157, B633, 2010.

50. Y. Y. Jo, E. Cho, J. H. Kim, T.-H. Lim, I.-H. Oh, S.-K. Kim, H.-J. Kim, and J. H. Jang, Degradation of polymer electrolyte membrane fuel cells repetitively exposed to reverse current condition under different temperature, J. Power Sources, Vol. 196, 9906, 2011.

51. L. Castanheira, L. Dubau, M. Mermoux, G. Berthomé, N. Caqué, E. Rossinot, M. Chatenet, F. Maillard, Carbon Corrosion in Proton-Exchange Membrane Fuel Cells: From Model Experiments to Real-Life Operation in Membrane Electrode Assemblies. ACS Catal. 2014, 4, 2258-2267;

52. L. Dubau, L. Castanheira, M. Chatenet, F. Maillard, J. Dillet, G. Maranzana, S. Abbou, O. Lottin, G. De Moor, A. El Kaddouri, C. Bas, L. Flandin, E. Rossinot, N. Caqué, Carbon corrosion induced by membrane failure: The weak link of PEMFC long-term performance. Int. J. Hydrogen Energy 2014, 39, 21902-21914.

53. J. Zhao, S. Shahgaldi, X. Li, Z. Liu, Experimental Observations of Microstructure Changes in the Catalyst Layers of Proton Exchange Membrane Fuel Cells under Wet-Dry Cycles, J. Electrochem. Soc., Vol. 165 (6), 2018.

54. N. Ge, R. Banerjee, D. Muirhead, J. Lee, H. Liu, P. Shrestha, A.K.C. Wong, J. Jankovic, M. Tam, D. Susac, J. Stumpere, A. Bazylak, Membrane dehydration with increasing current density at high inlet gas relative humidity in polymer electrolyte membrane fuel cells, Journal of Power Sources, Vol. 422, pp. 163-174, 2019. 